\title{
Procedure of the preparatory works execution during the remediation of high-rise buildings debris due to the disaster
}

\author{
Denis Sinitsyn ${ }^{1 *}$ \\ ${ }^{1}$ Moscow State University of Civil Engineering, Yaroslavskoe shosse, 26, Moscow, 129337, Russia
}

\begin{abstract}
The article covers one of the preparatory works types, in particular - the debris clearance. The types of machines and machinery, the purposes of the debris clearance, as well as the tasks for decrease of debris mass and scope are specified herein. The purpose of the article is to show the current level of the domestic machinery, as well as to share the experience of preparatory works. The article describes one of the preparatory works types, in particular - the debris clearance during the high-rise buildings demolition. Given are the equipment and machinery types, covered are the purposes and procedure of debris clearance defined are the tasks on reduction of debris mass and sizes. Specified are the types and methods of the preparatory works execution. The purpose of this article is to demonstrate the domestic equipment current state, and to share the experience in preparatory works execution.
\end{abstract}

\section{Introduction}

Nowadays the main task of preparatory works, under the conditions of new facility construction, is the development of required and safe conditions for the main works execution. To execute the preparatory works, upon management decision in some cases, developed is the project documentation concerning their execution procedure. The following shall be reflected in the work execution design: types of the preparatory works and their order of priority; the shortest and the most safe traffic routs through the facility territory, access ways to the certain buildings, facilities as well as the areas of sites development for the machinery arrangement; methods of walls demolition or dismantling, of the debris moving; technical solutions on the temporary fastening arrangement of the certain structures and elements, threatening to collapse failure; technical solutions on the equipment protection $[1,2,3,4,5,6,7]$.

The preparatory works are divided at the site of their execution into the off-site works executed beyond the company territory, and the intrasite ones executed at the company territory. The preparatory works are divided into the following types:

- debris clearance;

- demolition of buildings and theirs parts;

${ }^{*}$ Corresponding author: slavinaay@mgsu.ru 
- temporary fastening of structures, threatening to collapse failure;

- equipment protection;

- use of materials from the debris clearance and storage of reusable materials and structures.

The debris clearance is executed for purposes of the site preparation for further reconstruction works at the facility, of remaining equipment withdrawal, as well as for assessment of damage and the opportunity of use of remaining structures, foundations, channels and utilities.

\section{Materials and Methods}

Depending on the task in hand the debris is cleared in part or in whole. The partial clearance is executed during the development of access ways and areas for the machinery arrangement and manipulation, as well as during the essential industrial equipment withdrawal.

The debris clearance in whole is executed during the territory clearing for further reconstruction. The general principle during the debris clearance is the works execution downwards and in all directions, where it is possible to clear the debris; if there is the insufficient quantity of such directions it is required to develop them intentionally.

It is recommended to clear the debris by straight-line flow method, which allows putting into effect promptly the available workforce and means, and using them in the most complete and smooth manner for the duration of works, as well as widely applying for overall mechanisation. To execute the debris clearance successfully along the separate directions, it is reasonable to develop the complex groups equipped with lifting machines, bulldozers, transport means, machines and apparatus for breakdown of shatters of structures and equipment, auxiliary and service machines. The group accepts the tasks and limits of works per shift, per day or several days. When executing the works in shifts, it is set the task for a day shift to clear the debris and dispose the structures, and for the night shift-to develop the working area for the day shift $[8,9,10]$.

The development of access ways and areas is executed for the purpose of free access directly to the work areas and for arrangement of mechanical means.

The access ways are arranged as single-line ones of 3-3,5 $\mathrm{m}$ in width, with siding lines every 200-250 $\mathrm{m}$ as the areas of 2,5-3,0 $\mathrm{m}$ in width and of 15-20 $\mathrm{m}$ in length.

The clearance is executed by means of the shatters displacing out of the access way using the heavy hydraulic-motored bulldozer of work equipment. The operation of the single bulldozer is possible only in the debris consisting mainly of brick shatters. The making of access ways in the debris of mixed type with high content of reinforced concrete components is possible only by applying the complex of machines. The complex contains 3-4 machines, for example, one bulldozer with the capacity of $180-220 \mathrm{~kW}$ with ripper or with means for separation of the debris components, and two or three bulldozers with the capacity of 70-80 $\mathrm{kW}$.

\section{Results}

The lead machine of the complex is the heavy bulldozer: it displaces, withdraws and removes the large-size shatters; the other bulldozers spread the access way for wheeled machines. In case of insufficient tractive force of even the heavy bulldozer, the heavy elements in debris are blasted or broken by the pneumatic tool. For these purposes, as a rule, the teams of construction machines are added with three or four persons with means for cutting of reinforcement and steel structures, as well as groups for works execution. 
The debris clearance for purpose of the territory complete clearing shall be executed as follows:

- Firstly, withdrawn and removed are the certain beams, columns, roof slabs and other long-length elements raised from the debris;

- Large remnants of demolished reinforced concrete structures (beams, trusses, etc) are preliminarily free from the other elements of debris, are broken into the smaller parts and then removed from the debris;

- Large brick or concrete blocks are removed in whole, if it is allowed by a lifting capacity dimensions of construction machines and transport means; if it is impossible, then they are preliminarily broken and separated into the smaller parts;

- Small shatters and material debris are used for filling and planning of the territory or carted away beyond the facility territory and bulked in the specially designated area [11].

The machine sets for the debris clearance shall consist of the bulldozers, автокранов, excavators, tractor loaders, compressor station, pneumatic tool, machines with diamond tool, hydraulic wedges, etc.

As a first approximation, the addition of construction machines into complexes may be performed according to Table 1 (where given are the four groups of buildings and the appropriate machines complexes). These machines may be replaced by machines of equivalent types, if required and depending on their availability in the train.

The content of groups of industrial buildings and the list of machines, which may be used for the debris clearance, are given below.

Table 1. The four groups of buildings and the appropriate machines complexes

\begin{tabular}{|c|c|c|}
\hline $\begin{array}{l}\text { No. of } \\
\text { group }\end{array}$ & Data on the building structure & $\begin{array}{l}\text { Machines for selection of complexes for the } \\
\text { debris clearance }\end{array}$ \\
\hline \multirow[t]{5}{*}{1} & \multirow[t]{2}{*}{$\begin{array}{l}\text { Industrial single storey buildings } \\
\text { with the height of } 10-15 \mathrm{~m}\end{array}$} & $\begin{array}{l}\text { Bulldozers of traction category 3-4t: DZ- } \\
29, \text { DZ-101A, DZ-42G, etc. }\end{array}$ \\
\hline & & Tractor loaders TO-18, TO-11 \\
\hline & \multirow[t]{3}{*}{$\begin{array}{l}\text { Industrial multi-storey brick } \\
\text { buildings with number of storeys: } \\
2,3,4,5\end{array}$} & $\begin{array}{l}\text { Hydraulic shovels, 3-4 grade, with the } \\
\text { shovel capacity of } 0,5-0,65 \mathrm{~m}^{3} \text { : EO- } 4322 \mathrm{~A} \\
(\mathrm{MRO}), \mathrm{EO}-4121, \mathrm{EO}-4221 \mathrm{~B}\end{array}$ \\
\hline & & $\begin{array}{l}\text { Truck cranes with a lifting capacity of } 4-10 \\
t \text { (the short-baseline ones are preferable): } \\
\text { KS-3662A, KS-3571 }\end{array}$ \\
\hline & & $\begin{array}{l}\text { Tipping lorries (KRAZ-256B) with the } \\
\text { lifting capacity of } 5-7 \mathrm{t}\end{array}$ \\
\hline \multirow[t]{6}{*}{2} & \multirow{4}{*}{$\begin{array}{l}\text { Industrial single storey } \\
\text { prefabricated buildings with bays } \\
\text { of } 12,18 \mathrm{~m} \text {, with the height to the } \\
\text { bottom of framework structures } \\
\text { of } 3,6-9,6 \mathrm{~m} \text {, with mass of } \\
\text { elements of 5-9 t, with the } \\
\text { columns step of } 6-12 \mathrm{~m}\end{array}$} & $\begin{array}{l}\text { Bulldozers of traction category } 10-15 \text { t: } \\
\text { DZ-27(160 h.p.), D-35 (180 h.p.) with } \\
\text { widener of blade }\end{array}$ \\
\hline & & Tractor loaders: TO-21, TO-24 \\
\hline & & $\begin{array}{l}\text { Tipping lorries with the lifting capacity of } \\
7-16 t\end{array}$ \\
\hline & & $\begin{array}{l}\text { Hydraulic shovels, 3-4 grade, with the } \\
\text { shovel capacity up to } 1 \mathrm{~m}^{3} \text { : EO-4121, EO- } \\
\text { 3322A; EO- } 4125\end{array}$ \\
\hline & \multirow{2}{*}{$\begin{array}{l}\text { Industrial multi-storey } \\
\text { prefabricated buildings with a } \\
\text { storey height of } 3,6 ; 4,8 ; 6 \mathrm{~m} \text {, the } \\
\text { bay width of } 2,3,4 \mathrm{~m} \text {, mass of } \\
\text { elements of } 4,7,12 \mathrm{t}\end{array}$} & $\begin{array}{l}\text { Truck cranes with a lifting capacity of 10- } \\
16 \text { t: KS-5263, MKG-10A, MKT-25 }\end{array}$ \\
\hline & & $\begin{array}{l}\text { Tipping lorries with the lifting capacity of } \\
7-16 t\end{array}$ \\
\hline
\end{tabular}




\begin{tabular}{|c|c|c|}
\hline \multirow[t]{5}{*}{3} & \multirow{5}{*}{$\begin{array}{l}\text { Industrial single storey } \\
\text { prefabricated buildings with bays } \\
\text { of } 18,24,30 \mathrm{~m} \text {, with the height to } \\
\text { the bottom of framework } \\
\text { structures of } 6-15 \mathrm{~m} \text {, mass of } \\
\text { elements of } 8-16 \mathrm{t} \text {, with the } \\
\text { columns step of } 12 \mathrm{~m} \\
\begin{array}{l}\text { Industrial multi-storey } \\
\text { prefabricated buildings with the } \\
\text { mass } 7-12 \mathrm{t}\end{array}\end{array}$} & $\begin{array}{l}\text { Bulldozers of traction category } 15-25 \mathrm{t}: \text { D- } \\
\text { 34, D-59, D-384, D-685, D-439A }\end{array}$ \\
\hline & & Tractor loaders: TO-21, TO-24 \\
\hline & & $\begin{array}{l}\text { Hydraulic shovels, 4-5 grade: EO-4121, EO } \\
-5122 \text {, EO-5124, EO-5015A }\end{array}$ \\
\hline & & $\begin{array}{l}\text { Truck cranes with the lifting capacity of } 25- \\
40 \text { t: KS-5363, KS-5122, KS- } 6371 \text { short- } \\
\text { baseline, MKG-25, SKS-40 }\end{array}$ \\
\hline & & $\begin{array}{l}\text { Tipping lorries with the lifting capacity of } \\
9-25 t\end{array}$ \\
\hline \multirow[t]{6}{*}{4} & \multirow{5}{*}{$\begin{array}{l}\text { Industrial single storey } \\
\text { prefabricated buildings with bays } \\
\text { of } 24,30,36 \mathrm{~m} \text {, with the height to } \\
\text { the bottom of framework } \\
\text { structures of } 12-18 \mathrm{~m} \text {, mass of } \\
\text { elements of } 15-35 \mathrm{t} \text {, with the } \\
\text { columns step of } 12 \mathrm{~m}\end{array}$} & Bulldozers of traction category $25 \mathrm{t}$ : DZ-34 \\
\hline & & Tractor loaders: TO-21, TO-24 \\
\hline & & $\begin{array}{l}\text { Hydraulic shovels, } 5 \text { grade: EO-5122, EO- } \\
5124 \text {, EO-5015A }\end{array}$ \\
\hline & & $\begin{array}{l}\text { Truck cranes with the lifting capacity of } 40 \\
t, 63 t\end{array}$ \\
\hline & & $\begin{array}{l}\text { Tracked jib cranes 40-100 t: SKG-40, SKG- } \\
100\end{array}$ \\
\hline & $\begin{array}{l}\text { Industrial multi-storey heavy- } \\
\text { duty buildings of mixed type with } \\
\text { the height of } 15-35 \mathrm{~m} \text {, mass of } \\
\text { elements of } 15-25 \mathrm{t}\end{array}$ & $\begin{array}{l}\text { Tipping lorries with the lifting capacity of } \\
16-45 t\end{array}$ \\
\hline
\end{tabular}

The calculation on number of machines and machinery for the debris clearance is based on the following:

- actual scope of works - mass of debris in tons or its volume in $\mathrm{m}^{3}$;

-fixed time limits of clearance, under the specified shiftwork and shifts duration;

- production capacity of available mechanical means;

While calculating the actual scope of works it is recommended to use Table 2; the production capacities of mechanical means on the debris clearance are given in Table 3.

The volume weight of debris, its content and structure during the demolition of some types of buildings.

Table 2. The actual scope of works

\begin{tabular}{|c|c|c|c|c|c|c|}
\hline \multirow[b]{3}{*}{$\begin{array}{l}\text { Type of } \\
\text { buildings }\end{array}$} & \multirow[b]{3}{*}{$\begin{array}{l}\text { Volume } \\
\text { weight } \\
\text { of debris } \\
\mathrm{t} / \mathrm{m}^{3}\end{array}$} & \multicolumn{5}{|c|}{ Content of shatters, weight $\%$} \\
\hline & & \multirow{2}{*}{$\begin{array}{l}\text { Brick } \\
\text { blocks up to } \\
1 \mathrm{~m}^{3} \\
\text { brick rubble }\end{array}$} & \multicolumn{3}{|l|}{ Shatters of } & \multirow{2}{*}{$\begin{array}{l}\text { Material } \\
\text { debris }\end{array}$} \\
\hline & & & $\begin{array}{l}\text { Reinforce } \\
\text { concrete and } \\
\text { concrete } \\
\text { structures up } \\
\text { to } 0,8 \mathrm{~m}^{3} \\
\end{array}$ & $\begin{array}{l}\text { Wooden } \\
\text { structures }\end{array}$ & $\begin{array}{l}\text { Steel } \\
\text { structures } \\
\text { (including the } \\
\text { machining } \\
\text { equipment) }\end{array}$ & \\
\hline $\begin{array}{l}\text { Brick } \\
\text { production } \\
\text { buildings }\end{array}$ & $\begin{array}{l}1,514- \\
1,297\end{array}$ & 25 & 55 & 3 & 10 & 7 \\
\hline $\begin{array}{l}\text { Brick } \\
\text { residential } \\
\text { buildings }\end{array}$ & $\begin{array}{l}1,087- \\
0,931\end{array}$ & 50 & 15 & 15 & 5 & 15 \\
\hline $\begin{array}{l}\text { Wooden } \\
\text { buildings }\end{array}$ & $\begin{array}{l}0,478- \\
0,399\end{array}$ & 10 & - & 80 & - & 10 \\
\hline
\end{tabular}




\begin{tabular}{|l|l|l|l|l|l|l|}
\hline $\begin{array}{l}\text { Large- } \\
\text { panel } \\
\text { buldings }\end{array}$ & $\begin{array}{l}0,982- \\
0,819\end{array}$ & - & 75 & 18 & 2 & 5 \\
\hline
\end{tabular}

Table 3. Production capacities of mechanical means on the debris clearance

\begin{tabular}{|c|c|c|}
\hline Name of works & $\begin{array}{l}\text { Unit of } \\
\text { meas. }\end{array}$ & $\begin{array}{l}\text { Production } \\
\text { capacity per } \\
\text { working hour }\end{array}$ \\
\hline $\begin{array}{l}\text { Debris clearance by excavator with loading to transport } \\
\text { means, with a shovel capacity, } \mathrm{m}^{3} \text { : } \\
0,3 \\
0,5 \\
1,0\end{array}$ & $\mathrm{~m}^{3}$ & $\begin{array}{l}12 \\
18 \\
40\end{array}$ \\
\hline $\begin{array}{l}\text { Debris clearance with displacing of mass by tractor- } \\
\text { bulldozers, type C-100 and T-141 at the distance of, m: } \\
10 \\
20 \\
30 \\
\end{array}$ & $\mathrm{~m}^{3}$ & $\begin{array}{l}50 \\
35 \\
30 \\
\end{array}$ \\
\hline $\begin{array}{l}\text { Debris clearance of access ways by bulldozers, with the } \\
\text { width of access way of } 3,5 \mathrm{~m} \text {, with a medium height of } \\
\text { debris, } \mathrm{m} \\
\text { Up to } 0,3 \mathrm{~m} \\
\text { Up to } 0,5 \mathrm{~m}\end{array}$ & $\mathrm{~m}$ & $\begin{array}{l}170-200 \\
100-150 \\
\end{array}$ \\
\hline $\begin{array}{l}\text { Transportation of blocks and material debris from the } \\
\text { debris clearance by using the tipping trucks, with loading } \\
\text { by excavator at the distance of, km: } \\
1 \\
2 \\
3 \\
5\end{array}$ & $\mathrm{~m}^{3}$ & $\begin{array}{l}5-8 \\
4-6 \\
3-5 \\
2-3\end{array}$ \\
\hline $\begin{array}{c}\text { Loading of blocks to transport means by mobile cranes. } \\
\text { Demolition by tractor of buildings walls with the height } \\
\text { of storeys: } \\
\text { Up to } 3 \\
\text { More }\end{array}$ & $\mathrm{m}^{2}$ & $\begin{array}{l}35 \\
20\end{array}$ \\
\hline
\end{tabular}

During the clearance of debris made by the brick buildings, the hydraulic shovel with convertible attachments (back or front shovel, pneumatic hammer or jack hammer) will take the lead in the complex. The shovel is used for clearance and loading of debris structure to the tipping trucks and for breakage of large brick blocks. The debris elements for loading will be displaced and grouped using by applying the bulldozer. In case of clearance of mixed type debris, consisting of demolished reinforced concrete and steel structures, at the first process stage the crane with the lifting capacity of 25-100 $t$ will be held the key place, with the radius of working range up to $30-40 \mathrm{~m}$. Such crane shall operate together with machine and equipment for cut through the reinforcement of reinforced concrete structures and steel structures. To decrease a mass and dimensions of debris shatters used are the methods equivalent to ones of buildings demolition or applied are the demolition means, specified in Table 4. The grinding is executed in situ or at the specific areas. The demolition means of the construction structure materials recommended during the preparatory works execution.

Table 4. The demolition means 


\begin{tabular}{|c|c|c|c|c|c|}
\hline $\begin{array}{c}\text { Demolition } \\
\text { means }\end{array}$ & $\begin{array}{l}\text { Productio } \\
\text { n capacity }\end{array}$ & $\begin{array}{c}\text { Effect of } \\
\text { demolition } \\
\text { mean to a } \\
\text { material }\end{array}$ & Process technology & $\begin{array}{l}\text { Recommended complex } \\
\text { of machines and } \\
\text { machinery }\end{array}$ & $\begin{array}{l}\text { Possibilit } \\
\text { y of } \\
\text { applicatio } \\
\mathrm{n} \text { indoor }\end{array}$ \\
\hline $\begin{array}{l}\text { Hydraulic- } \\
\text { wedged } \\
\text { plants }\end{array}$ & $\begin{array}{c}0,45-20 \\
\mathrm{~m}^{3} / \mathrm{hr} \text { per } \\
\text { one } \\
\text { breaking } \\
\text { device } \\
\text { (hydraulic } \\
\text {-wedged) }\end{array}$ & $\begin{array}{l}\text { Breaking of } \\
\text { concrete } \\
\text { and } \\
\text { reinforced } \\
\text { concrete } \\
\text { masses to } \\
\text { pieces }\end{array}$ & $\begin{array}{c}\text { Preparation to works: } \\
\text { blast-hole drilling; } \\
\text { arrangement of } \\
\text { hydraulic-wedged } \\
\text { breaking device in a } \\
\text { blast hole. Breaking. } \\
\text { Clearance of broken } \\
\text { parts }\end{array}$ & $\begin{array}{c}\text { Pneumatic drill IP-4701 } \\
\text { or PR-20L, compressor } \\
\text { ZIF SVE 4,8/1,0SHR, } \\
\text { CMJ-83 (ISP-400), } \\
\text { hydraulic-wedged } \\
\text { breaking device (it is } \\
\text { possible to use several } \\
\text { breaking devices) }\end{array}$ & Possible \\
\hline $\begin{array}{c}\text { Jack } \\
\text { hammers and } \\
\text { pneumatic } \\
\text { hammers }\end{array}$ & $\begin{array}{c}1,5-3,5 \\
\mathrm{~m}^{3} / \mathrm{hr}\end{array}$ & $\begin{array}{l}\text { Complete } \\
\text { demolition }\end{array}$ & $\begin{array}{l}\text { Preparation to works: } \\
\text { material demolition. } \\
\text { Disposal of } \\
\text { demolished concrete } \\
\text { from the area of } \\
\text { demolition. }\end{array}$ & $\begin{array}{c}\text { Base excavator EO- } \\
4121 \text {, jack hammer SP- } \\
62\end{array}$ & $\begin{array}{c}\text { Possible } \\
\text { provided } \\
\text { that the } \\
\text { height of } \\
\text { premises } \\
\text { is more } \\
\text { than } 8,4 \\
\mathrm{~m}\end{array}$ \\
\hline $\begin{array}{c}\text { Diamond } \\
\text { drilling plant }\end{array}$ & $\begin{array}{c}1,2-4,8 \\
\mathrm{~m}^{3} / \mathrm{hr} \\
\text { (opening/ } \\
\mathrm{hr} \text { ) }\end{array}$ & $\begin{array}{l}\text { Making of } \\
\text { opening, } \\
\text { formation } \\
\text { of slots, } \\
\text { severing of } \\
\text { reinforced } \\
\text { concrete, } \\
\text { concrete } \\
\text { and brick } \\
\text { structures }\end{array}$ & $\begin{array}{c}\text { Preparation to } \\
\text { clearance. Drilling of } \\
\text { openings. Disposal of } \\
\text { demolished material }\end{array}$ & $\begin{array}{l}\text { Diamond drilling } \\
\text { machine, set of diamond } \\
\text { drills, compressor ZIF } \\
\text { SVE } 4,8 / 1,0 \text { SHR }\end{array}$ & Possible \\
\hline $\begin{array}{c}\text { Pneumatic } \\
\text { and electric } \\
\text { demolition } \\
\text { hammers }\end{array}$ & $\begin{array}{c}0,25-0,6 \\
\mathrm{~m}^{3} \text { per } \\
\text { shift }\end{array}$ & $\begin{array}{l}\text { Breaking of } \\
\text { concrete }\end{array}$ & $\begin{array}{l}\text { Preparation. Breaking. } \\
\text { Disposal of } \\
\text { demolished material }\end{array}$ & $\begin{array}{c}\text { Demolition hammer } \\
\text { ZUBR ZM-40-1700 K }\end{array}$ & Possible \\
\hline $\begin{array}{c}\text { Flame jet } \\
\text { burner }\end{array}$ & - & $\begin{array}{l}\text { Severing of } \\
\text { concrete } \\
\text { and } \\
\text { reinforced } \\
\text { concrete } \\
\text { made in } \\
\text { any } \\
\text { position }\end{array}$ & $\begin{array}{c}\text { Preparation to } \\
\text { severing. Severing. } \\
\text { Disposal of separated } \\
\text { material }\end{array}$ & Set. Oxygen containers & $\begin{array}{c}\text { Possible } \\
\text { provided } \\
\text { the safety } \\
\text { and } \\
\text { ventilatio } \\
\mathrm{n} \\
\text { procedure } \\
\text { complian } \\
\text { ce }\end{array}$ \\
\hline $\begin{array}{c}\text { Oxygen } \\
\text { lance. } \\
\text { Powder- } \\
\text { oxygen } \\
\text { cutting plant }\end{array}$ & $\begin{array}{c}1,5-5,1 \\
\mathrm{~m} / \mathrm{hr}\end{array}$ & $\begin{array}{l}\text { Oxygen } \\
\text { lance } \\
\text { drilling. } \\
\text { Cutting }\end{array}$ & $\begin{array}{l}\text { Preparation to works. } \\
\text { Cutting to the depth of } \\
4 \mathrm{~m} \text {. Clearance of } \\
\text { demolished material }\end{array}$ & $\begin{array}{l}\text { Metal tube } 3-5 \mathrm{~m} \text { in } \\
\text { length. Oxygen } \\
\text { containers. Plant, type } \\
\text { UPKR-2 }\end{array}$ & $\begin{array}{c}\text { Possible } \\
\text { provided } \\
\text { the } \\
\text { overventil } \\
\text { ation }\end{array}$ \\
\hline $\begin{array}{l}\text { Blasting } \\
\text { materials }\end{array}$ & $\begin{array}{l}0,55-0,59 \\
\mathrm{~m}^{3} / \mathrm{hr} . \\
\text { Thickness } \\
\text { of the } \\
\text { material } \\
\text { to be } \\
\text { demolishe } \\
\text { d - any }\end{array}$ & $\begin{array}{c}\text { Breaking to } \\
\text { pieces in } \\
\text { any } \\
\text { position of } \\
\text { a structure }\end{array}$ & $\begin{array}{l}\text { Preparation to works: } \\
\text { blast-hole drilling. } \\
\text { Blast. Disposal of } \\
\text { products after the blast }\end{array}$ & Blasting materials & $\begin{array}{c}\text { Limited } \\
\text { due to } \\
\text { seismic } \\
\text { effect and } \\
\text { shatters } \\
\text { distributio } \\
n\end{array}$ \\
\hline $\begin{array}{l}\text { Blasting } \\
\text { generator } \\
\text { VN-2 }\end{array}$ & $\begin{array}{l}45-150 \\
\mathrm{~m}^{3} / \mathrm{hr}, \\
\text { number of } \\
\text { blasts per } \\
1 \text { minute } \\
80-1500 .\end{array}$ & $\begin{array}{l}\text { Breakage in } \\
\text { any } \\
\text { position of } \\
\text { a structure }\end{array}$ & $\begin{array}{c}\text { Preparation to works. } \\
\text { Breakage }\end{array}$ & $\begin{array}{l}\text { Blasting generator VN- } \\
\text { 2. Hydraulic shovel, } \\
\text { 3grade, or machine } \\
\text { KrAZ-257K }\end{array}$ & $\begin{array}{c}\text { Limited } \\
\text { due to } \\
\text { large } \\
\text { dimensio } \\
\text { ns }\end{array}$ \\
\hline
\end{tabular}




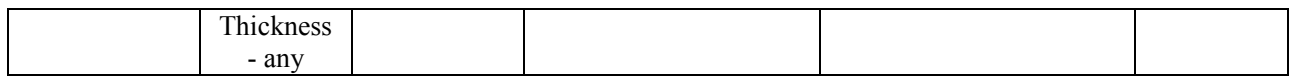

After the withdrawal and clearance of large components of the debris started working the universal hydraulic shovels with the shovel's capacity of $0,65-1,25 \mathrm{~m}^{3}$, and the wheeled tractor shovels. The final process of the debris clearance is the loading and disposal of damaged structures shatters and material debris to the waste tips. When selecting the transport diagram of the debris clearance, it should be considered that the favourable ratio of capacity of the excavator shovel and the tipping lorry body is the ratio $1: 4$ or 1:5.

The preliminary lifting capacity of transport means depending on the excavator shovel capacity is accepted as per Table 5 .

Table 5. The preliminary lifting capacity of transport means

\begin{tabular}{|c|c|}
\hline $\begin{array}{c}\text { Capacity of the loading } \\
\text { machines shovels }\left[\mathrm{m}^{3}\right]\end{array}$ & Lifting capacity of the tipping lorry $[\mathrm{t}]$ \\
\hline $0,3-04$ & $3,5-10$ \\
\hline $0,5-1$ & $7-10$ \\
\hline $1,25-2$ & $10-25$ \\
\hline $3-4$ & $25-40$ \\
\hline
\end{tabular}

In Fig. 1. given are the process flow diagrams of the lumped debris clearance (characterized by the side lengths ratio as 1:1) and the extended debris clearance (characterized by the side lengths ratio as more than 1:2) [12]. 


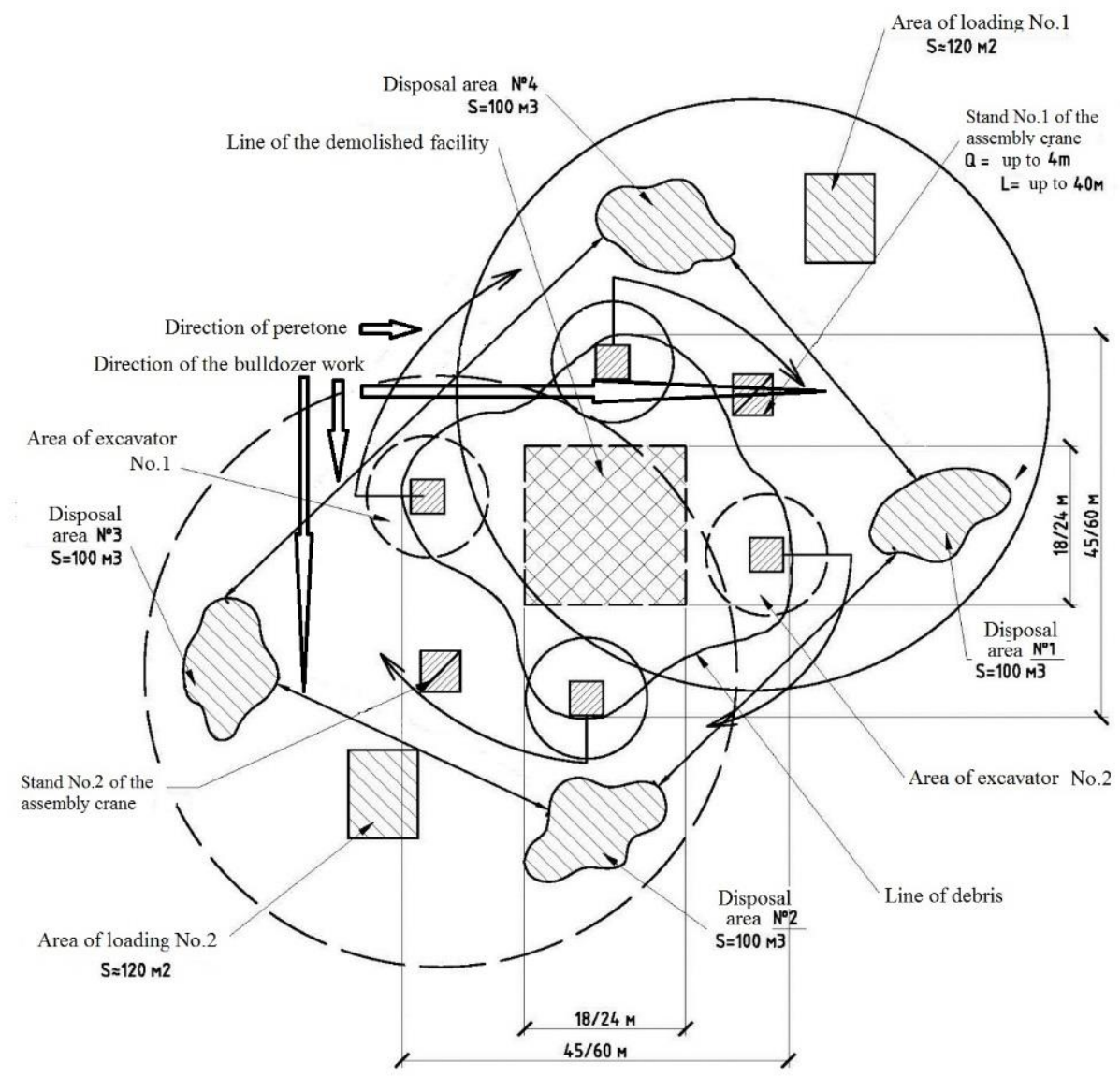

Fig. 1. Debris clearance of the lumped facility.

\section{Conclusions}

The upgrading and use of new machinery allow applying the new design and process solutions. The types and purposes of the debris clearance, the selection of machines and machinery, tasks for decrease of the debris mass and dimensions, selection of a certain type of motor transport depend on the technical-and-economic characteristics, characteristics of the machines, duration and length of haul. Generally, it is preferable to use the specific types of transport for the debris clearance - the hydraulic-motored bulldozers and excavators.

\section{References}

1. P.P. Oleynik Construction organization. Conceptual frameworks. Models and methods. Information-utility systems. (2001)

2. B.V. Zhadanovskiy Machining of concrete and reinforced concrete by the diamond tool, Ind. and civ. constr. 4 (2017) 
3. M.S. Vainshtein, B.V. Zhadanovskiy, S.A. Sinenko, A.A. Afanas'yev et al Selection of methods for construction and installation works mechanization, Sc. Rev., 13, 123-127 (2015)

4. T.V. Zolina Application for assessment methods of operation life of industrial building with cranage throughout its life cycle, Astrakhan, AISI (2014)

5. T.V. Zolina, Vestnik MGSU, 14, 98-108 (2014)

6. B. V. Zhadanovsky Organizational and technological solutions for labor safety in work production (Moscow, ASV Publ., 2015)

7. A. Ginzburg, S Kachanov International Journal of Applied Engineering Research ISSN 0973-4562 10, (20), pp 40869-40872 (2015)

8. B.V. Zhadanovskiy, Sinenko S.A., Kuzin F. Journal of Technology and organization of construction production. 1(6), pp.38 (2014)

9. B.F. Shirshikov, et al Organizational-process solutions on the labour safety in the work execution designs (2015)

10. T K. Kuz'mina, Sinenko S A Basic forms of implementation of the customer functions upon the major investment-construction projects organization and management Science review 7 pp 222-227 (2016)

11. M.N. Ershov, Lapidus A.A. Modern technologies of civil buildings reconstruction, (Moscow, ACB, 2014)

12. SV. Shatov News of PUBA.. 7-8 (172-173). pp.39-44 (2012) 